\title{
Coprophagous hydrophilid beetles (Coleoptera: Hydrophilidae) as carriers of phoretic deutonymphs of Uropoda orbicularis (Acari: Mesostigmata) in Poland
}

\author{
DARIA BAJERLEIN ${ }^{1}$ and MAREK PRZEWOŹNY ${ }^{2}$
}

\author{
${ }^{1}$ Department of Animal Taxonomy and Ecology, Adam Mickiewicz University, Umultowska 89, 61-614 Poznań, Poland; \\ e-mail: bajer@amu.edu.pl \\ ${ }^{2}$ Department of Systematic Zoology, Adam Mickiewicz University, Fredry 10, 61-701 Poznań, Poland; \\ e-mail: marekprzewozny@poczta.onet.pl
}

Key words. Coprophagous beetles, Hydrophilidae, Uropoda orbicularis, Acari, phoresy, Poland

\begin{abstract}
During a study 20 hydrophilid beetle species and 2,457 individuals of beetles belonging to 4 genera: Cercyon, Cryptopleurum, Megasternum and Sphaeridium were collected. On the surface of the bodies of 59 beetles (2.40\% of the beetles collected) belonging to six species, 174 cases of phoresy [55 deutonymphs of Uropoda orbicularis (Müller, 1776) and 119 pedicels without deutonymphs] were observed. New hydrophilid beetle carriers of phoretic deutonymphs of $U$. orbicularis are given. Most mites were carried by Sphaeridium species. The population dynamics of both groups of arthropods was also studied. Most cases of phoresy were recorded in May and in the second half of July. However, phoretic deutonymphs were not present on the body surface of hydrophilid beetles throughout the whole period of this study.
\end{abstract}

\section{INTRODUCTION}

There are many papers on phoresy of uropodid mites on scarabaeid beetles (e.g. Costa, 1963; Stewart \& Davis, 1967; Chmielewski, 1977; Hunter \& Rosario, 1988; Mašán, 1994; 2001; Gwiazdowicz, 2000; Kofler \& Schmölzer, 2000; Błoszyk et al., 2002; Bajerlein \& Błoszyk, 2004; Haitlinger, 2004). In contrast, phoresy of uropodid mites on hydrophilid beetles is poorly known. Deutonymphs of $U$. orbicularis have been found on hydrophilid beetles by Faasch (1967) and Karg (1989). Kofler \& Schmölzer (2000) give only Cercyon impressus as the carrier of deutonymphs of U. orbicularis and Uroobovella obovata (Canestrini, Berlese 1884) in Austria. Bajerlein \& Błoszyk (2004) included hydrophilid beetles in their study of the deployment of phoretic deutonymphs of $U$. orbicularis on the body surface of beetles that inhabit cow dung in Poland, but do not cite the species.

The main purpose of this study was to determine the species of hydrophilid beetles that carry phoretic deutonymphs of $U$. orbicularis and determine whether phoretic deutonymphs show a preference for a particular species of carrier. Moreover, the infestation rates of beetles by phoretic deutonymphs and the population dynamices of both groups of arthropods were recorded.

Among Hydrophilidae one group of species inhabits aquatic habitats - subfamily Hydrophilinae and another belonging to the subfamily Sphaeridiinae inhabits dung (e.g. Cercyon, Cryptopleurum, Megasternum, Sphaeridium). The majority of studies on Hydrophilidae in Poland focus on those species that inhabit aquatic habitats (e.g. Buczyński \& Przewoźny, 2002; Przewoźny, 2002; Przewoźny \& Buczyński, 2002; 2003; Bidas \& Przewoźny, 2003; Buczyński et al., 2003; Przewoźny \& Lasoń, 2003). There is a lack of data on coprophagous hydrophilid beetles in Poland. Therefore, this paper is not only concerned with the phenomenon of phoresy of uropodid mites on hydrophilid beetles but it also gives new data on coprophagous hydrophilid beetles in Poland.

\section{MATERIAL AND METHODS}

The research was carried out on a pasture about $20 \mathrm{~km}$ northwest of Poznań (Wielkopolska province, Poland) from March to November 2003. Beetles and the deutonymphs attached to their body surface were collected using 6 pitfall traps (Bunalski, 1996). The traps were emptied at 7 day intervals. The lure substrate was cow dung. The beetles and mites were preserved in $75 \%$ ethyl alcohol. The beetles with phoretic deutonymphs were identified directly in $75 \%$ ethyl alcohol (in order to preserve the deutonymphs) and beetles without mites were dried before identification (dried beetles are easier to identify). The beetles were identified under a stereomicroscope using the keys of Freude et al. (1971), Hansen (1987, 1990), Hebauer (1989) and Hebauer \& Schödl (1998). The systematics of hydrophilid beetles follows that of the Checklist of Polish Hydrophiloidea (Przewoźny, 2004).

Phoretic deutonymphs were mounted on microscope slides and subsequently determined using the keys by Karg (1989) and Mašán (2001). All cases of phoresy were noted - deutonymphs and pedicels without deutonymphs were recorded separately.

The value of dominance (D) for each species of beetle was the total number of specimens of that species divided by the total number of hydrophilid beetles collected during the whole season. The infestation of beetles by deutonymphs was estimated using the prevalence, intensity and density values used by Skoracka (2004). Prevalence is the number of beetles carrying mites divided by the total number of beetles expressed as a percentage. Intensity is the mean number of cases of phoresy (deutonymphs and pedicels) per infested beetle. Density is the mean number of cases of phoresy per hydrophilid beetle. We also found phoretic deutonymphs of $U$. orbicularis on beetles belonging to the families Staphylinidae, Histeridae, Aphodiidae, Geotrupidae and Scarabaeidae. Most cases of phoresy were recorded for dung beetles (Aphodiidae, Geotrupidae and Scarabaeidae). This material is deposited in the Department of Animal Taxonomy and Ecology, Adam Mickiewicz University. 
TABLE 1. The list of species of coprophagous hydrophilid beetles (Hydrophilidae) collected, with their abundance, dominance and number of cases of phoresy: deutonymphs and pedicels, recorded on particular species of beetle (N - beetle abundance; $\mathrm{D}$ - beetle dominance; DN - the number of phoretic deutonymphs; PD - the number of pedicels (without deutonymphs); DP - the total number of deutonymphs and pedicels).

\begin{tabular}{|c|c|c|c|c|c|c|}
\hline & Species of beetle & $\mathrm{N}$ & $\mathrm{D}(\%)$ & DN & PD & DP \\
\hline & Cercyon & & & & & \\
\hline 1 & Cercyon pygmeus (Illiger, 1801) & 989 & 40.25 & 0 & 0 & 0 \\
\hline 2 & Cercyon lateralis (Marsham, 1802) & 481 & 19.58 & 5 & 4 & 9 \\
\hline 3 & Cercyon haemorrhoidalis (Fabricius, 1775) & 60 & 2.44 & 2 & 3 & 5 \\
\hline 4 & Cercyon quisquilius (Linnaeus, 1761) & 25 & 1.02 & 0 & 0 & 0 \\
\hline 5 & Cercyon atricapillus (Marsham, 1802) & 8 & 0.33 & 0 & 0 & 0 \\
\hline 6 & Cercyon impressus (Sturm, 1807) & 4 & 0.16 & 0 & 0 & 0 \\
\hline 7 & Cercyon melanocephalus (Linnaeus, 1758) & 4 & 0.16 & 0 & 0 & 0 \\
\hline 8 & Cercyon obsoletus (Gyllenhal, 1808) & 2 & 0.08 & 0 & 0 & 0 \\
\hline 9 & Cercyon analis (Paykull, 1798) & 1 & 0.04 & 0 & 0 & 0 \\
\hline 10 & Cercyon laminatus Sharp, 1873 & 1 & 0.04 & 0 & 0 & 0 \\
\hline 11 & Cercyon terminatus (Marsham, 1802) & 1 & 0.04 & 0 & 0 & 0 \\
\hline \multirow[t]{2}{*}{12} & Cercyon unipunctatus (Linnaeus, 1758) & 1 & 0.04 & 0 & 0 & 0 \\
\hline & Cryptopleurum & & & & & \\
\hline 1 & Cryptopleurum minutum (Fabricius, 1775) & 260 & 10.58 & 0 & 0 & 0 \\
\hline 2 & Cryptopleurum subtile Sharp, 1884 & 6 & 0.24 & 0 & 0 & 0 \\
\hline \multirow[t]{2}{*}{3} & Cryptopleurum crenatum (Panzer, 1794) & 2 & 0.08 & 0 & 0 & 0 \\
\hline & Megasternum & & & & & \\
\hline \multirow[t]{2}{*}{1} & Megasternum obscurum (Marsham, 1802) & 11 & 0.45 & 0 & 0 & 0 \\
\hline & Sphaeridium & & & & & \\
\hline 1 & Sphaeridium lunatum Fabricius, 1792 & 236 & 9.61 & 39 & 28 & 67 \\
\hline 2 & Sphaeridium scarabeoides (Linnaeus, 1758) & 159 & 6.47 & 8 & 77 & 85 \\
\hline 3 & Sphaeridium marginatum Fabricius, 1787 & 142 & 5.78 & 1 & 1 & 2 \\
\hline \multirow[t]{2}{*}{4} & Sphaeridium bipustulatum Fabricius, 1781 & 64 & 2.60 & 0 & 6 & 6 \\
\hline & Total & 2457 & 100.00 & 55 & 119 & 174 \\
\hline
\end{tabular}

\section{RESULTS}

During the study, 2,457 hydrophilid beetles belonging to 20 species from the following genera: Cercyon, Cryptopleurum, Megasternum and Sphaeridium were collected. On the body surface of 59 beetles, 174 cases of phoresy ( 55 deutonymphs of $U$. orbicularis and 119 pedicels without deutonymphs) were observed.

The list of beetle species with information on whether they carried deutonymphs or pedicels without deutonymphs, their abundance $(\mathrm{N})$ and dominance (D) are given in Table 1 .

The maximum number of cases of phoresy found on one beetle was 37. Most cases of phoresy were observed in May and at the end of July. The prevalence value was $2.40 \%$ for the whole season, but varied between $0.00 \%$ and $25.00 \%$. The intensity value was 2.95 for the whole season and varied between 1.00 and 7.50. The density value was 0.07 for the whole season and varied between 0.00 and 1.88 . The highest values for all the indices were observed in the middle of July.

The population dynamics of the hydrophilid beetles and incidence of phoresy is shown in Figs 1-2. The cases of phoresy involving $U$. orbicularis and coprophagous hydrophilid beetles did not occur throughout the whole season. The first phoretic deutonymphs were observed at the begining of May, and one week earlier pedicels without deutonymphs. The last phoretic deutonymphs were observed at the end of August (Fig. 3).

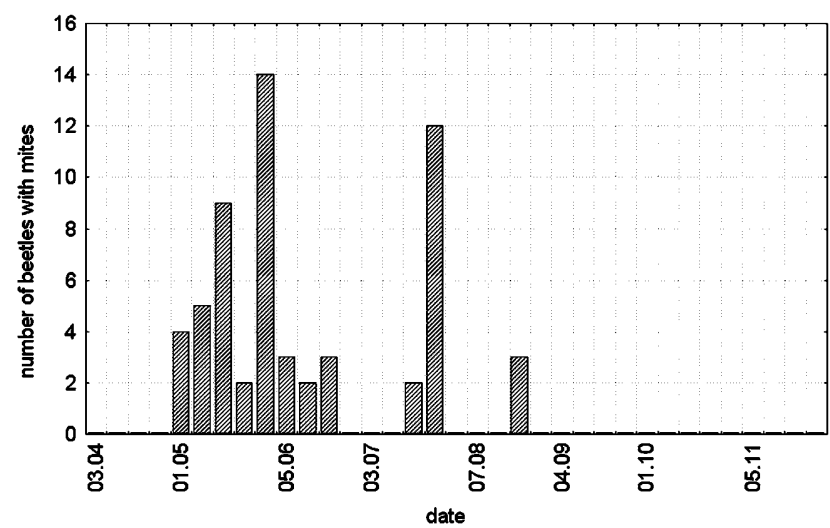

Fig. 1. Population dynamics of coprophagous hydrophilid beetles (Hydrophilidae) carrying mites (abundance of hydrophilid beetles in Figs 1-2 expressed as the total number of beetles collected from 6 traps on a particular date; dates in the figures are the first sampling date in a particular month). 


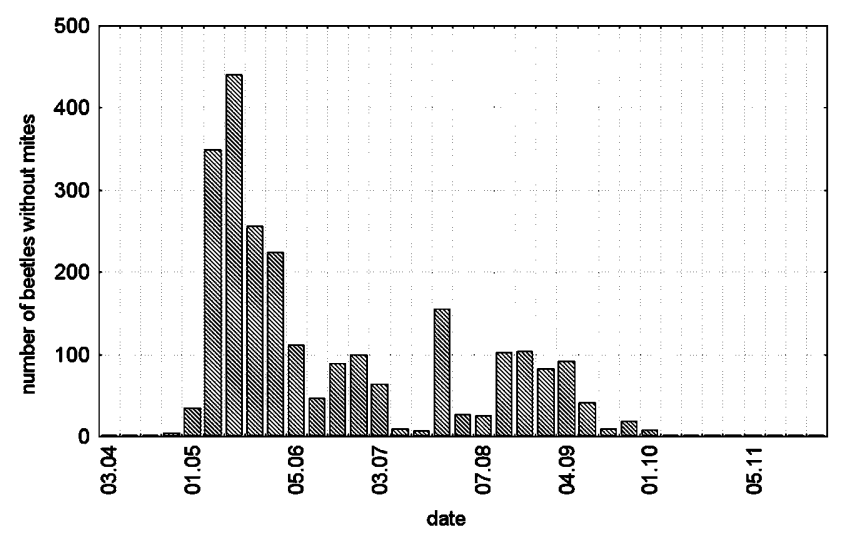

Fig. 2. Population dynamics of coprophagous hydrophilid beetles (Hydrophilidae) not carrying mites.

\section{DISCUSSION}

Uropoda orbicularis is known to be phoretic on a wide range of dung beetles (e.g. Faash, 1967; Makarova, 1995; Haitlinger, 1999; Gwiazdowicz, 2000; Mašán, 2001; Bajerlein \& Błoszyk, 2004). However, phoresy of U. orbicularis and other uropodid mites on coprophagous hydrophilid beetles was poorly studied until now.

During this study, all coprophagous hydrophilid beetle species known from Poland, except Sphaeridium substriatum Faldermann, 1838, were found. Cases of phoresy were recorded for six species: Cercyon lateralis, C. haemorrhoidalis, Sphaeridium scarabaeoides, S. lunatum, S. marginatum and S. bipustulatum. However, on the body surface of $S$. bipustulatum only pedicels without deutonymphs were observed. All these beetle species are reported for the first time as carriers of deutonymphs of $U$. orbicularis in Poland.

The fact that phoresy was recorded for six $(30 \%)$ of the 20 species, seems to indicate that this group of beetles does not play an important role in dispersal of deutonymphs of $U$. orbicularis. In comparison, during spring over 17,000 cases of phoresy were recorded on 19 of the 25 species of dung beetles (Scarabaeoidea), collected at the same time as the hydrophilid beetles. The values for prevalence, intensity and density were also higher in the case of dung beetles.

The fact that most cases of phoresy were for species belonging to genus Sphaeridium and few for the two Cercyon species (of the 12 species recorded), may be explained by the size of the beetles. Species of Sphaeridium are the biggest of all the coprophagous hydrophilid beetles collected and probably therefore prefered by phoretic deutonymphs. In comparison, phoresy on Cercyon seems to be accidental. This is supported by the fact, that phoretic deutonymphs were not carried by Cercyon pygmeus, which was the most numerous species and made up $40 \%$ of the beetle community.

The abundance of phoretic deutonymphs of $U$. orbicularis on coprophagous hydrophilid beetles is presented for the first time. Most cases of phoresy were observed in May and in the second half of July, which is probably associated with the higher abundance of beetles at that time.

ACKNOWLEDGEMENTS. We thank two anonymous reviewers for their thorough reviews and the Editor of the European Journal of Entomology for the remarks which improved the paper. We are also very grateful to J. Błoszyk and W. Magowski (Department of Animal Taxonomy and Ecology, Adam Mickiewicz University) for their comments on the manuscript. The study was supported by the research project No.

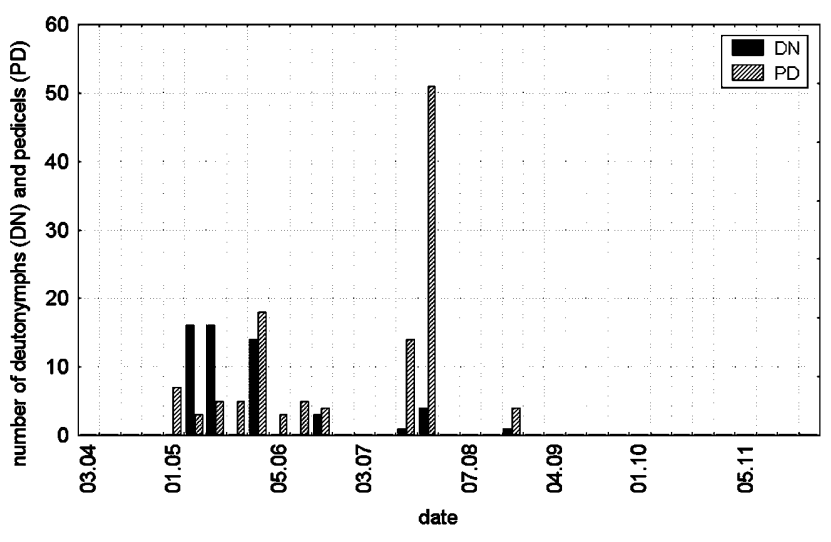

Fig. 3. Population dynamics of phoretic $U$. orbicularis divided into deutonymphs (DN) and pedicels (PD) (abundance of deutonymphs and pedicels expressed as the total number of deutonymphs and pedicels found on all beetles collected on a particular date; dates in the figure are the first sampling date in a particular month).

PBWB-504/2004 from the Faculty of Biology, Adam Mickiewicz University.

\section{REFERENCES}

BAJERLein D. \& BłoszyK J. 2004: Phoresy of Uropoda orbicularis by beetles (Coleoptera) associated with cattle dung in Poland. Eur. J. Entomol. 101: 185-188.

BidAs M. \& PRZEWoźNy M. 2003: Contribution to the knowledge Hydrophiloidea (Coleoptera) of the Świętokrzyskie Mountains. Wiad. Entomol. 22: 5-12 [in Polish, English abstr.].

Błoszyk J., Bajerlein D., Skoracka A., Stachowiak M. \& BAJACZYK R. 2002: Uropoda orbicularis (Müller, 1776) (Acari: Uropodina) as an example of a mite adapted to synanthropic habitats. In Tajovský K. \& Pižl V. (eds): Studies on Soil Fauna in Central Europe. Proc. $6^{\text {th }}$ CEWSZ, ISB AS CR. 2002. J. Posekaný, České Budějovice, pp. 7-11.

BuCZyŃSKI P. \& PRZEWOŹNY M. 2002: Water beetles (Coleoptera) of the Krzczonowski Landscape Park. Parki Nar. Rez. Przyr. 21: 283-297 [in Polish, English abstr.].

BuczyŃski P., Kowalik W. \& Przewoźny M. 2003: Water beetles (Coleoptera: Haliplidae, Noteridae, Dytiscidae, Hydrochidae, Helophoridae, Hydrophilidae) collected in Lublin City during the years 1967-1972. Wiad. Entomol. 22: 55-56 [in Polish].

BunALSKI M. 1996: Ecofaunistic studies on coprophagous beetles. Methods. Part. II. Biul. Entomol. 4: 5-6 [in Polish].

Chmielewski W. 1977: Results of observations on associations of mites with insects (Acari: Insecta). Pol. Pismo Entomol. 47: 59-78 [in Polish, English abstr.].

Costa M. 1963: The mesostigmatic mites associated with Copris hispanus (L.) (Coleoptera, Scarabaeidae) in Israel. J. Linn. Soc. (Zool.). 45: 25-45.

FAASCH H. 1967: Beitrag zur Biologie der einheimischen Uropodiden Uroobovella marginata (C.L. Koch 1839) und Uropoda orbicularis (O.F. Müller 1776) und experimentelle Analyse ihres Phoresieverhaltens. Zool. Jb. Syst. 94: 521-608.

Freude H., Harde K.W. \& Lohse G.A. 1971: Adephaga 2, Palpicornia, Histeroidea, Staphylinoidea 1. Die Käfer Mitteleuropas 3. Goecke \& Evers, Krefeld, 365 pp.

GwiAzDowicz D.J. 2000: Mites (Acari, Gamasida) associated with insects in the Białowieża National Park. Acta Parasitol. 45: 43-47. 
HAITLINGER R. 1999: Mites (Acari) occurring on Geotrupes stercorosus, G. mutator and Typhoeus typhoeus (Coleoptera: Scarabaeidae) in Poland. Pol. Pismo Entomol. 68: 319-336.

Haitlinger R. 2004: Mites (Acari) occurring on some Coleoptera (Insecta) in Poland. Pol. Pismo Entomol. 73: 3-24.

Hansen M. 1987: The Hydrophiloidea (Coleoptera) of Fennoscandia and Denmark. Fauna Entomol. Scand. 18: 1-254.

Hansen M. 1990: De danske arter af slægten Sphaeridium Fabricius (Coleoptera, Hydrophilidae). Entomol. Meddr 58: 59-64 [in Danish, English abstr.].

Hebauer F. 1989: Familienreiche Hydrophiloidea. In: Lohse G. A. \& Lucht W. H. Die Käfer Mitteleuropas. Supplementband mit Katalogteil 1. Goecke \& Evers, Krefeld, pp. 72-92.

Hebauer F. \& SchöDl S. 1998: Familie Hydrophilidae In: Lucht W. \& Klausnitzer B.: Die Käfer Mitteleuropas 4. Supplementband, Goecke \& Evers, Krefeld, pp. 97-106.

Hunter P.E. \& Rosario R.M.T. 1988: Associations of Mesostigmata with other Arthropods. Annu. Rev. Entomol. 33: 393-417.

KARG W. 1989: Acari (Acarina), Milben Unterordnung Parasitiformes (Anactinochaeta) Uropodina Kramer, Schildkrötenmilben. Gustav Fischer Verlag, Jena, 203 pp.

Kofler A. \& SCHMÖLzer K. 2000: Zur Kenntnis phoretischer Milben und ihrer Tragwirte in Österreich (Acarina: Gamasina, Uropodina). Ber. Nat. Med. Verein Innsbruck 87: 133-157.

Makarova O. 1995: Mesostigmatic mites (Parasitiformes, Mesostigmata) on the forest dung beetle Geotrupes stercorosus. Zool. Zh. 74: 16-23.
MašÁn P. 1994: The mesostigmatic mites (Acarina, Mesostigmata) associated with the dung beetles (Coleoptera, Scarabaeidae) in South Slovakia. Biologia (Bratislava) 49: 201-205.

MAŠÁN P. 2001: Mites of the cohort Uropodina (Acarina, Mesostigmata) in Slovakia. Ann. Zool. Botan. 223: 1-320 [in Slovakian, English abstr.].

PrZewoźNY M. 2002: Hydrophilidae (Coleoptera) new to the Wielkopolska-Kujawy Lowlands. Wiad. Entomol. 21: 183-184 [in Polish].

PrzewoźnY M. 2004: New localities of the Hydrophiloidea in Poland. Wiad. Entomol. 23: 69-80 [in Polish, English abstr.].

PRZEwoźNY M. \& BucZYŃsKi P. 2002: Preliminary data about water beetles (Coleoptera) of the "Iławskie Lake District" Landscape Park (North Poland). Rocz. Nauk. Pol. Tow. Ochr. Przyr. "Salamandra" 6: 137-139 [in Polish].

PrzewoźNY M. \& BuczyŃsKi P. 2003: Hydrochus flavipennis Küster, 1852 (Coleoptera: Hydrochidae), a new species for the fauna of Poland. Pol. Pismo Entomol. 72: 229-233.

Przewoźny M. \& Lasoń A. 2003: Some species of Hydrophilidae (Coleoptera) new to Podlasie region and Lublin Uplands. Wiad. Entomol. 22: 60-61 [in Polish].

Skoracka A. 2004: Eriophyoid mites from grasses in Poland. Genus (Suppl.) 13: 205 pp.

STEWART T.B. \& DAVIS R. 1967: Notes on mites associated with coprophagous beetles. J. Georgia Entomol. Soc. 2: 21-26.

Received June 30, 2004; revised October 12, 2004; accepted November 29, 2004 